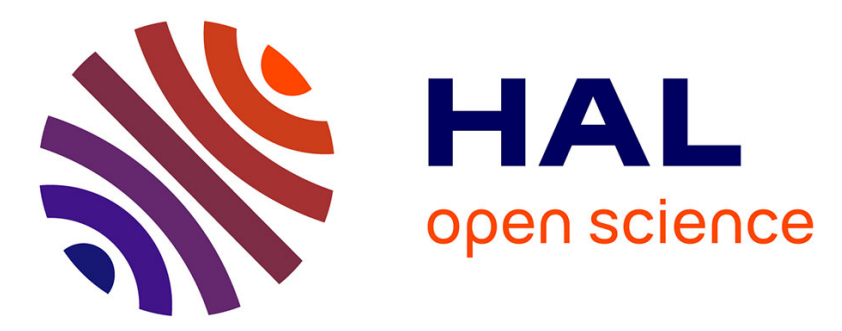

\title{
Mesomegaloprepidae, a remarkable new damselfly family (Odonata: Zygoptera) from mid-Cretaceous Burmese amber
}

Diying Huang, Dany Azar, Chenyang Cai, Sibelle Maksoud, André Nel, Günter Bechly

\section{To cite this version:}

Diying Huang, Dany Azar, Chenyang Cai, Sibelle Maksoud, André Nel, et al.. Mesomegaloprepidae, a remarkable new damselfly family (Odonata: Zygoptera) from mid-Cretaceous Burmese amber. Cretaceous Research, 2017, 10.1016/j.cretres.2017.01.003 . hal-01437568

\section{HAL Id: hal-01437568 \\ https://hal.sorbonne-universite.fr/hal-01437568}

Submitted on 17 Jan 2017

HAL is a multi-disciplinary open access archive for the deposit and dissemination of scientific research documents, whether they are published or not. The documents may come from teaching and research institutions in France or abroad, or from public or private research centers.
L'archive ouverte pluridisciplinaire HAL, est destinée au dépôt et à la diffusion de documents scientifiques de niveau recherche, publiés ou non, émanant des établissements d'enseignement et de recherche français ou étrangers, des laboratoires publics ou privés. 
Mesomegaloprepidae, a remarkable new damselfly family (Odonata: Zygoptera) from mid-Cretaceous Burmese amber

(1)

Diying Huang a*, Dany Azar a,b, Chenyang Cai a , Sibelle Maksoud a,b, André Nel ${ }^{\text {c*}}$, Günter Bechly ${ }^{d}$

(1)

a State Key Laboratory of Palaeobiology and Stratigraphy, Nanjing Institute of Geology and Palaeontology, Chinese Academy of Sciences, Nanjing 210008, People’s Republic of China (dyhuang@nigpas.ac.cn)

${ }^{b}$ Lebanese University, Faculty of Sciences II, Department of Biology, Fanar Matn P.O. Box 26110217,Lebanon(azar@mnhn.fr)

${ }^{c}$ Institut de Systématique, Évolution, Biodiversité, ISYEB - UMR 7205 - CNRS, MNHN, UPMC, EPHE, Muséum national d'Histoire naturelle, Sorbonne Universités, 57 rue Cuvier, CP 50, Entomologie F-75005, Paris, France (anel@mnhn.fr)

d Staatliches Museum für Naturkunde Stuttgart, Rosenstein 1, D-70191 Stuttgart, Germany (guenter.bechly@smns-bw.de)

\footnotetext{
* Corresponding authors:
}

E-mail addresses: dyhuang@nigpas.ac.cn (D.-y. Huang); anel@mnhn.fr (A. Nel)

\section{ABSTRACT}

Mesomegaloprepus magnificus gen. et sp. nov. (Odonata: Zygoptera) is described from more than 14 specimens in eight pieces of mid-Cretaceous (earliest Cenomanian, ca. $99 \mathrm{Ma}$ )

Burmite amber from Myanmar. Possible phylogenetic affinities with the Neotropical Latibasaliidae, Thaumatoneuridae, and Pseudostigmatinae are discussed, and a relationship with Pseudostigmatinae considered as possible, but because of conflicting evidence separate 
27 family status as Mesomegaloprepidae fam. nov. is tentatively preferred. The remarkable degree of homoplastic conflict in the wing venational similarities indicates that these represent relatively weak evidence for phylogenetic relationships. The palaeoecology, including sexual dimorphism in wing coloration, of the new taxon is discussed, and the large number of inclusions explained with possible breeding behaviour in association with waterfilled tree holes (phytotelmata) of the amber tree, similar to extant Pseudostigmatinae. The position of all alleged fossil Thaumatoneuridae are discussed and revised: Eothaumatoneura ptychoptera Pongracz, 1935 from the Eocene Geiseltal locality is restored in Thaumatoneuridae. Cretaceous Euarchistigma and Paleogene Eodysagrion are tentatively retained as subfamilies Euarchistigmatinae and Eodysagrioninae in Thaumatoneuridae.

Paleogene Dysagrioninae and Petrolestinae are removed from Thaumatoneuridae and attributed to a restored family Dysagrionidae, and Paleocene Latibasaliidae is transferred from Amphipterygoidea to Epallagoidea.

Keywords:

Pseudostigmatinae

Thaumatoneuridae

Latibasaliidae

Cenomanian

Myanmar

Phylogeny 


\section{Introduction}

Descriptions of fossil damselflies in Cretaceous amber were relatively rare until the recent palaeoentomological studies on the mid-Cretaceous amber from Myanmar, work which has already resulted in the description of seven species from the families Hemiphlebiidae, Perilestidae, Dysagrionidae, Platystictidae, and Platycnemididae (Poinar et al., 2010; Huang et al., 2015; Zheng et al., 2016a, b, c, in press), with further descriptions in preparation by the authors.

Here, we describe a remarkable new fossil damselfly taxon, Mesomegaloprepus magnificus gen. et sp. nov. (Zygoptera: Mesomegaloprepidae fam. nov.) (Fig. 1), from eight amber pieces with more than 14 conspecific inclusions in 99 Ma Burmese amber. This fossil shows curious similarities with the extant tropical families Thaumatoneuridae and Pseudostigmatidae, giving us an occasion to discuss the position of the fossil taxa currently considered in these two clades (see Supplementary material).

\section{Materials and methods}

Fossils were examined and measured using an incident light stereomicroscope (Olympus SZX9) and a stereomicroscope (Nikon SMZ 1500), as well as a Leitz Wetzlar binocular microscope. Photographs were taken using a Zeiss Discovery V20 microscope system. Optical instruments were equipped by camera lucida and digital cameras. The raw digital images were processed with focus stacking software, and figure plates prepared with Adobe Photoshop ${ }^{\mathrm{TM}}$.

We follow the wing venation nomenclature of Riek and Kukalová-Peck (1984), emended by Nel et al. (1993) and Bechly (1996). The higher classification of fossil and extant Odonatoptera, as well as characters for family diagnoses, are largely based on the phylogenetic system proposed by Bechly (1996, 2003). Several recent works that have 
addressed the higher phylogeny of Zygoptera (Dumont et al., 2010; Davis et al., 2011; Dijkstra et al., 2013, 2014) have been taken into account.

\subsection{Burmese amber}

The specimens are preserved in eight pieces of relatively clear, yellow Burmite amber. The amber pieces were polished before being examined and photographed. The amber piece with paratype NIGP 161753 has been included in a glass coffin with Canada Balsam as medium for better examination. All amber material was legally acquired in Myanmar from local traders with government registration, and legally exported according to the official regulations in Myanmar.

Fossil-bearing has mostly been collected from the Hukawng Valley in northern Myanmar (formerly known as Burma). For an overview of the amber deposit and its geological setting see, e.g., Zherikhin and Ross (2000), Grimaldi et al. (2002), Cruickshank and Ko (2003), and Ross et al. (2010). Radiometric U-Pb zircon dating (Shi et al., 2012) recently constrained this amber to a minimum age of $98.79 \pm 0.62 \mathrm{Ma}$, which is equivalent to the mid-Cretaceous (earliest Cenomanian). The original habitat of the amber forest is still controversial, in fact it has originally been assumed to be a tropical araucarian forest (Grimaldi et al., 2002; Poinar et al., 2007), possibly with Dipterocarpaceae as another source for the fossil resin. However, the first detailed report on the macromolecular nature and palaeobotanical affinity of Burmite (Dutta et al., 2011), based on gas chromatography - mass spectrometry, rejected Araucariaceae and Dipterocarpaceae in favour of Pinaceae as the Burmese amber tree. Grimaldi (2016), after Grimaldi and Ross (in press), considered 'based on the abundant inclusions of leafy shoots' that it was formed by a conifer, and 'amber produced possibly by Metasequoia (Taxodiaceae) or a close relative'. Even though fossil and extant Pinaceae are generally absent from south of the equator and from tropical rainforests in 
particular, a notable exception is Pinus krempfii from the rainforests of Vietnam (Brodribb and Feild, 2008).

The family, genus, and species are registered in Zoobank under the urn:lsid:zoobank.org:act:CFC6346B-B702-4A83-B436-6D3730E73C9C

\section{Systematic palaeontology}

\section{Order Odonata Fabricius, 1793}

Suborder Zygoptera Selys, 1854

Family Mesomegaloprepidae fam. nov.

Type-genus. Mesomegaloprepus gen. nov.

Diagnosis. As for the genus, since it is presently monotypic (see below).

Genus Mesomegaloprepus gen. nov.

Type-species. M. magnificus sp. nov.

Etymology. Named after the Mesozoic period and the extant pseudostigmatine genus Megaloprepus Rambur, 1842, with which it shares several wing venational similarities including a unique triadic branching of vein MP. The gender of the name is masculine. Diagnosis. Male ligula with distal segment modified to form a very long single flagellum; wings with extensive brown colour (as preserved) pattern and very dense wing venation with a several hundreds of cells; secondary antenodal crossveins absent, except for three accessory crossveins between C and ScP distal of Ax2; series of five to seven crossveins in antesubnodal space; nodus in a very basal position, at about $20 \%$ of wing length; more than sixty postnodal crossveins; postnodal and postsubnodal crossveins not aligned; discoidal cell 
rectangular and crossed by a single crossvein; distal side MAb of discoidal cell not oblique or with reversed obliquity; subdiscoidal cell traversed by two crossveins; base of RP2 far distal of subnodus; vein $\mathrm{CuP}$ between $\mathrm{M}+\mathrm{Cu}$ and $\mathrm{AA}$ instead of being between $\mathrm{M}+\mathrm{Cu}$ and $\mathrm{A}$; bases of RP3/4 and IR2 (midfork) basally recessed midway between arculus and nodus (instead of aligned with subnodus); longitudinal wing veins distally distinctly curved to posterior wing margin; CuA long, extending well beyond mid wing level, with numerous curved posterior branches and characteristical triadic branching pattern of CuA and apical part of MP (but not MA, which is unbranched); no intercalary veins between MP and CuA; pterostigma in apical position, short and rectangular (parallel-sided); pterostigmal brace reduced; no lestine oblique vein 'O'; absence of several rows of cells between costal margin, RA, and RP1 near wing apex.

Mesomegaloprepus magnificus sp. nov.

Figs. 2-8

Etymology. The specific epithet is after the wonderful colored wings of these damselflies.

Holotype. Holotype female NIGP 164902, allotype male NIGP161753, deposited at Nanjing Institute of Geology and Palaeontology, P.R. China.

Paratypes. Female NIGP161754; male NIGP 164903; male NIGP 164904; NIGP 164950; NIGP 164951, all deposited at Nanjing Institute of Geology and Palaeontology; SMNS Bu-231 deposited at the State Museum of Natural History Stuttgart, Germany. Type-locality and stratum. Tanai Village, Hukawng Valley, Kachin State, northern Myanmar. Burmite, mid-Cretaceous (earliest Cenomanian), ca. 99 Ma (Shi et al., 2012). 
Diagnosis. As for the genus, since it is presently monotypic (see above), wings dark

152

153

154

brown with a hyaline apex, in males with posterior hyaline patch in distal cubital area, and in females with narrow hyaline transverse band near base of RP2 (sexual dimorphism).

\section{Descriptions.}

Holotype female NIGP 164902. A head and thorax with three wings attached. Wings basal halves dark brown, then a narrow hyaline transverse zone, followed by a second dark zone and wing apex hyaline; forewing ca. $29.0 \mathrm{~mm}$ long (preserved part $26.0 \mathrm{~mm}$ long), 8.7 mm wide, $3.7 \mathrm{~mm}$ wide at nodus level; distance from base to arculus $2.4 \mathrm{~mm}$, from arculus to nodus $3.2 \mathrm{~mm}$; nodus in a basal position, more than 19\% of wing length; petiole very short, $0.8 \mathrm{~mm}$ long, $1.0 \mathrm{~mm}$ wide; distance from base to Ax1 $1.8 \mathrm{~mm}$, from Ax1 to Ax2 $0.8 \mathrm{~mm}$; arculus distinctly basal of Ax2; 3 accessory secondary antenodal crossveins between C and ScP distal of Ax2, but none between ScP and RA; antesubnodal space with a regular series of crossveins; numerous postnodal crossveins not well aligned with postsubnodal crossveins; pterostigma present but not colored, no pterostigmal brace; bases of RP3/4 and IR2 (midfork) basally recessed midway between arculus and nodus; IR2 apparently arising on RP3/4; basal space between RP3/4 and IR2 not narrowed; area between RP and MA between arculus and base of RP3/4 without a crossvein; base of RP2 far distal from subnodus; no oblique crossvein; two secondary longitudinal veins between MA and MP in distal part, both apparently emerging from MP; discoidal cell crossed, rectangular, with MAb of inverted obliquity; subdiscoidal cell traversed by two crossveins; CuP between $\mathrm{M}+\mathrm{Cu}$ and AA; anal area rather wide with a series of small transverse cells between AA and AP; cubital area broad, CuA long with numerous curved posterior branches and characteristically triadic branching pattern of $\mathrm{CuA}$; area between $\mathrm{MP}$ and $\mathrm{CuA}$ broader than postdiscoidal area in their basal parts; no intercalary vein between MP and CuA.

Allotype NIGP161753. The amber piece is $3.5 \mathrm{~cm}$ long and $0.5 \mathrm{~cm}$ wide. This specimen (Figs. 2-3) features head, thorax, and the four basal abdominal segments, two fore 
177 legs, one mid leg, one hind leg, two-third of left forewing and bases of the two hind wings attached. Head transverse, 5.0 mm wide, with eyes well separated, distance between eyes ca. $4.0 \mathrm{~mm}$; ocelli disposed in triangle on a low protuberance between eyes. Legs with long spines on femora and tibiae. Abdomen ca. $2.0 \mathrm{~mm}$ wide (it is not visible if there is a secondary copulatory apparatus on the second segment or not). Forewing uniformly dark brown owing oxidation; forewing ca. $29.0 \mathrm{~mm}$ long (preserved part $26.0 \mathrm{~mm}$ long), $8.7 \mathrm{~mm}$ wide, $3.7 \mathrm{~mm}$ wide at nodus level; distance from base to arculus $2.4 \mathrm{~mm}$, from arculus to nodus $3.2 \mathrm{~mm}$; nodus in a basal position, more than 19\% of wing length; petiole very short, $0.8 \mathrm{~mm}$ long, $1.0 \mathrm{~mm}$ wide; distance from base to Ax1 $1.8 \mathrm{~mm}$, from Ax1 to Ax2 $0.8 \mathrm{~mm}$; arculus distinctly basal of Ax2; 3 accessory secondary antenodal crossveins between C and ScP distal of Ax2, but none between ScP and RA; antesubnodal space with a regular series of crossveins; numerous postnodal crossveins not well aligned with postsubnodal crossveins; pterostigma present but not colored, no pterostigmal brace; bases of RP3/4 and IR2 (midfork) basally recessed midway between arculus and nodus; IR2 apparently arising on RP3/4; basal space between RP3/4 and IR2 not greatly narrowed; area between RP and MA between arculus and base of RP3/4 with a crossvein; base of RP2 far distal from subnodus; no oblique crossvein; two secondary longitudinal veins between MA and MP in distal part, both apparently emerging from MP; discoidal cell crossed, rectangular, with MAb of inverted obliquity; subdiscoidal cell traversed by two crossveins; CuP between $\mathrm{M}+\mathrm{Cu}$ and AA; anal area rather wide with a series of small transverse cells between AA and AP; cubital area broad, CuA elongate with numerous curved posterior branches and characteristically triadic branching pattern of $\mathrm{CuA}$; area between MP and $\mathrm{CuA}$ broader than postdiscoidal area in their basal parts; no intercalary vein between MP and CuA.

Paratype NIGP 161754. The amber piece with this paratype is $2.6 \mathrm{~cm}$ long and $0.5 \mathrm{~cm}$ wide. This specimen (Fig. 2e-f) features fragments of thorax with part of head and first basal abdominal segments still attached, plus bases of the two right wings and the basal half of left 
forewing. The preserved parts of wing are nearly identical in proportions and venation to those of the holotype, documenting the conspecific status. Head transverse with eyes well separated. Thorax ca. $2.8 \mathrm{~mm}$ wide and ca. $4.0 \mathrm{~mm}$ high. Abdomen $2.0 \mathrm{~mm}$ wide; no secondary copulatory apparatus on segments 2-3 (thus a female specimen). Forewing dark brown with a narrow lighter transverse band distal of nodus, near base of RP2, forewing with preserved part ca. $18.0 \mathrm{~mm}$ long, $3.3 \mathrm{~mm}$ wide at nodus level; distance from base to nodus 4.4 $\mathrm{mm}$, nodus in a very basal position; petiole very short, $1.2 \mathrm{~mm}$ long; Ax2 about opposite arculus; area between RP and MA between arculus and base of RP3/4 without any crossvein. Paratype NIGP 164903. This specimen features a nearly complete abdomen of a male, with a nearly complete hind wing attached to fragments of the thorax and two wing apices, as well as isolated legs with very long spines. It has the same proportions and wing venation as the holotype (including arculus distinctly basal of Ax2); nevertheless its area between RP and MA between arculus and base of RP3/4 is without any crossvein. The wing has a brown colour pattern except for the translucent apex and distal cubital area. This specimen clearly shows the male secondary copulatory apparatus of abdominal segment 2, with a ligula having its distal segment modified to form a very long single flagellum, reaching segment 3; a series of strong spines on the genital lobes; anterior hamuli well developed with a smooth point. Paratype NIGP 164950. This specimen features 10 isolated wings of male and female specimens that probably represented a mating group. The wings are largely identical to those of the allotype NIGP 161753 (including arculus distinctly basal of Ax2), except in the area between RP and MA between arculus and base of RP3/4 without any crossvein. The colour pattern is similar to the other specimens. The Pterostigmata are covering 2.5-3.5 narrow cells beneath them.

Paratype NIGP 164951. This specimen features six isolated wings (probably of a mating pair) without preserved bodies. The wings are also identical to the holotype. The colour patterns are similar to those of the other specimens. 
Paratype male NIGP 164904. This specimen features a male with head, thorax and part of the abdomen, plus wings. The wings are also identical to the holotype. The colour patterns are similar to those of the other specimens.

Paratype SMNS Bu-231. This specimen features partially preserved bodies of three specimens (incl. male and female), with fragments of all wings and legs bearing very long spines. The wing venations are very similar to those of the allotype (including arculus distinctly basal of Ax2) and the colour pattern is similar to those of the other specimens. Notable differences are: antesubnodal space with seven crossveins but no crossveins in the basal third (right wings of female); midfork (origin of IR2 and RP3/4) is not in midway position between subnodus and arculus but further recessed close to arculus (right hind wing of female); subdiscoidal cell traversed by two crossveins in the forewing, but only one in the hind wing (right wings of female); pterostigma covering three narrow cells beneath it (in the female).

\section{Discussion}

\subsection{Phylogenetic relationships}

Placement of Mesomegaloprepidae fam. nov. is challenging owing to conflicting evidence. Mesomegaloprepus gen. nov. shows venational similarities with three different known family-group taxa of Neotropical damselflies, viz. Latibasaliidae (genus Latibasalia Petrulevičius and Nel, 2004), Coenagrionidae-Pseudostigmatinae (esp. genus Megaloprepus), and Thaumatoneuridae (esp. genus Thaumatoneura McLachlan, 1897).

\subsubsection{Comparison with Latibasaliidae Petrulevičius and Nel, 2004}

Latibasaliidae (Zygoptera: Amphipterygoidea) are an enigmatic fossil family from the Paleogene (Upper Palaeocene) of Argentina (Petrulevičius and Nel 2004, 2007). A potential 
relationships with the fossil genera Petrolestes Cockerell, 1927 and Congqingia Zhang, 1992 (Amphipterygoidea: Thaumatoneuridae) was discussed in the original description, because they share the absence of secondary antenodal crossveins and the absence of antesubnodal crossveins. However, these characters are very homoplastic and weak. We transfer here Latibasaliidae from Amphipterygoidea to Epallagoidea as sister group of Zacallitidae, because of the shared convex longitudinal intercalary vein in the cubital field as unique putative synapomorphy.

Mesomegaloprepus shows several similarities with Latibasaliidae: arculus distinctly basal of Ax2; Ax1 and Ax2 close together; very oblique nodal and subnodal veinlets; postnodal crossveins not aligned with postsubnodal crossveins (symplesiomorphy); pterostigmal brace reduced; midfork (origins of IR2 and RP3/4) recessed distinctly basal of subnodus; discoidal cell quadrangular; distal side MAb of discoidal cell with reversed obliquity; cubital space expanded with several rows of cells; longitudinal veins distally strongly curved; secondary intercalary branches between RP3/4 and MA, and between MA and MP; no lestine oblique vein 'O'; wings with dark banded colour pattern.

However, Mesomegaloprepus differs from Latibasaliidae in several important characters: nodus in more basal position; midfork mid way between arculus and subnodus (instead of being recessed much closer to arculus); basal side of pterostigma not oblique; triadic branchings of CuA. Further potential differences (viz. secondary antenodals between C and ScP distal of Ax2, several antesubnodal crossveins, and subdiscoidal cell divided) are not totally certain, because the corresponding wing areas seem not very well preserved in the known specimens of Latibasaliidae.

The mentioned differences in Mesomegaloprepus are all derived states that could be autapomorphies; so they would not contradict a relationship with Latibasaliidae. However, many of the similarities are either of uncertain polarity, or symplesiomorphies, or homoplastic, so that the evidence for a relationship is weak and inconclusive. We therefore 
can neither exclude nor establish a sister group relationship of Mesomegaloprepidae with Latibasaliidae. Nevertheless, the densely reticulated wings with short petiolus, and especially the rectangular shape of the discoidal cell with a distal side MAb with reversed obliquity would support a position in Epallagoidea (new position for Latibasaliidae), and the expanded cubital field would agree with Zacallitidae (here recognized as sister group of Latibasaliidae). Furthermore, the recession of the midfork, the reduced pterostigmal brace and lestine oblique vein 'O', as well as the coloured wings would support a position in Caloptera (Calopterygoidea sensu Dijkstra et al., 2013), if this group is monophyletic at all, which is rather doubtful (Dijkstra et al., 2014).

\subsubsection{Comparison with Pseudostigmatinae Kirby, 1890 (sensu Dijkstra et al., 2013)}

$$
\text { Pseudostigmatinae (formerly classified as distinct family Pseudostigmatidae) is a }
$$
group of mainly Neotropical giant damselflies (also known as helicopter damselflies) that oviposit in phytotelmata, where the dendrolimnetic larvae develop. Adults pluck orb-weaver spiders and their prey from spider webs (Fincke, 1984; Clausnitzer, 2002). The extremely long abdomen is apparently not developed for oviposition in phytotelmata but used as balance while hovering in front of spider webs (Clausnitzer, 2002). The only Pseudostigmatinae outside of the Neotropical realm is the Eastern African Coryphagrion grandis Morton, 1924, which was formerly classified in a monotypic separate family Coryphagrionidae Pinhey, 1962, but recognized as most closely related to or belonging to Pseudostigmatinae by Bechly (1996, 2003), Clausnitzer and Lindeboom (2002), Rehn (2003), Groeneveld et al. (2007), Yu and Bu (2011), and Ingley et al. (2012). Coryphagrion Morton, 1924 is very similar to Mecistogaster Rambur, 1842. Like all Neotropical Pseudostigmatinae, it oviposits in phytotelmata and exclusively feeds on spiders and insects picked out of spider webs (Lounibos, 1980; Clausnitzer, 2002; Clausnitzer and Lindeboom, 2002). All Neotropical 
genera have a more or less reduced pterostigma and males have characteristical hamuli anteriores and a terminal single flagellum on the ligula (Schmidt, 1915; Dijkstra et al., 2014), while Coryphagrion has retained a normal pterostigma and lacks the terminal ligula flagellum (Kimmins, 1931; Dijkstra et al., 2014). Morphological and genomic data have shown that the Pseudostigmatinae (incl. Coryphagrion) nest deeply within Coenagrionidae and thus should be classified within this family (Ramírez, 1997; Bybee et al., 2008; Carle et al., 2008; Yu and Bu, 2011; Ingley et al, 2012; Dijkstra et al., 2014). Dijkstra et al. (2013) therefore formally sunk the family Pseudostigmatidae in Coenagrionidae, where it forms a subfamily Pseudostigmatinae with three tribes (Bechly, 1996, 2003; Ingley, 2012): Coryphagrionini (only including Coryphagrion as sister group to Neotropical pseudostigmatines),

Pseudostigmatini (including the two narrow-winged genera Mecistogaster and Pseudostigma Selys, 1860 with simple longitudinal veins), and Megaloprepini (broad-winged genera Microstigma Rambur, 1842, Anomisma McLachlan, 1877, and Megaloprepus , with characteristic triadic branchings of longitudinal veins MA and CuA). The phylogeny and character distribution shows that narrow wings without triadic branchings represent the plesiomorphic ground plan condition, from which derived broad winged forms evolved (Bechly, 1996, 2003; Ingley, 2012). The extant genus Megaloprepus represents the largest known damselfly of all times with a wingspan of up to $19 \mathrm{~cm}$ and an abdomen length of 10 cm (Groeneveld et al., 2007).

Putative synapomorphies of Mesomegaloprepus with Pseudostigmatinae (incl. Coryphagrionini) are as follows: similar shape of wing with very dense venation and a large number of cells (also present in Thaumatoneura); very basal position of nodus at about 20\% of wing length (also present in Thaumatoneura), correlated with a basal recession of the midfork at about $25 \%$ of wing length, and a high number of postnodal veins and an origin of RP2 far distal of subnodus; discoidal cell elongated (also present in Thaumatoneuridae); IR2 apparently arising from RP3/4 (as in Thaumatoneuridae); more than two rows of cells 
between RP1 and RP2 (also present in Thaumatoneura), with very long IR1 and a shorter negative intercalary between IR1 and RP1 (very much like Pseudostigmatinae, and unlike Thaumatoneura); pterostigma very short, rectangular, and in apical position. Finally the possible association with phytotelmata (see below) might represent evidence for a relationship with Pseudostigmatinae (incl. Coryphagrion), but also occurs by convergence in some unrelated tropical damselfly and dragonfly taxa. However, the following plesiomorphies of Mesomegaloprepus contradict a placement within the crown group of Pseudostigmatinae or even in Coenagrionoidea: much smaller size (all Pseudostigmatinae show gigantism); presence of three accessory secondary antenodal crossveins between $\mathrm{C}$ and ScP distal of Ax2 (unknown in Coenagrionoidea, but 1-2 present in Thaumatoneura); multiple antesubnodal crossveins (unknown in Coenagrionoidea); postnodal and postsubnodal crossveins not aligned (unknown in Coenagrionoidea, but present in Thaumatoneura); RA and RP1 not sigmoidally curved at apex, and RP1 and RP2 not converging apically; basal part of space between IR2 and RP3/4 not strongly narrowed; only a single row of cells between C and RA at apex (two or more rows in Pseudostigmatinae, except for some but not all specimens of Coryphagrion and Mecistogaster, but also Thaumatoneuridae). Mesomegaloprepus differs from nearly all known Coenagrionidae (including all Pseudostigmatinae), with the sole exception of Protoneurinae s.str. (subfamily of Coenagrionidae according to Dijkstra et al., 2014), in the rectangular shape of the discoidal cell (as in Thaumatoneura, and less developed in Megaloprepus). Also Mesomegaloprepus differs from all known Coenagrionoidea (including all Pseudostigmatinae) in the position of the arculus distinctly basal of Ax2 (but the polarity of this character is unclear), the recession of the midfork (origins of IR2 and RP3/4) distinctly basal of subnodus (a derived state that never occurs in Coenagrionoidea and Thaumatoneuridae, but is typical for Lestoidea and "Calopterygoidea”), and the presence of several secondary (intercalary) longitudinal veins in the median and radial areas (as in Thaumatoneuridae). 
Putative synapomorphies with Neotropical Pseudostigmatinae (Pseudostigmatini +

Megaloprepini)) are as follows: pterostigmal brace reduced (as in Thaumatoneura; still braced in Coryphagrion); male secondary genital apparatus with distal segment of ligula modified into a very long single flagellum (absent in Coryphagrion). The following plesiomorphies of Mesomegaloprepus contradict a placement in the crown group of Neotropical

Pseudostigmatinae: RA, RP1, and IR1 not apically strongly curved towards the hind margin and converging to the same point at the hind margin (only reversed in Anomisma); only a single row of cells between RP1 and IR1 (like Coryphagrion, but unlike all other Pseudostigmatinae and Thaumatoneuridae); normal pterostigma present (replaced by pseudopterostigma in all Neotropical Pseudostigmatinae). The very short parallel-sided pterostigma of Mesomegaloprepus could be interpreted as precursor of the further reduction of the pterostigma in Neotropical Pseudostigmatinae, but the presence of a normal pterostigma rather than a pseudo-pterostigma would still exclude any position within the crown group Pseudostigmatinae and especially any closer relationship with Megaloprepus.

Putative synapomorphies with broad-winged Pseudostigmatinae (Megaloprepini) are as follows: broad shape of wings; CuA very long with numerous curved posterior branches, and triadic branching pattern of CuA (also present in Thaumatoneura); furcation of RP into RP1 and RP2 shifted into distal half of wing, thus base of RP2 very far distal of subnodus (as in Thaumatoneura). However, the following plesiomorphies of Mesomegaloprepus contradict a placement in the crown group of the broad-winged Pseudostigmatinae and thus refute a potential sister group relationship with either Anomisma or Megaloprepus: pterostigma present; absence of the typical triadic branching of apical MA, and apical furcation of RP3/4; distally only a single row of cells between RA and RP (at least two rows in Megaloprepini, but also at apex of Thaumatoneuridae); only a single row of cells between RP1/2 and RP3/4 between the RP forks (as in Thaumatoneuridae). 
Putative synapomorphies with the extant genus Anomisma (Pseudostigmatinae:

385

386

387

388

389

390

391

392

Megaloprepini) are as follows: discoidal cell divided (unique autapomorphy within

Coenagrionidae, and unlike the undivided discoidal cell in Thaumatoneura); subdiscoidal cell

divided by two crossveins (vs only one in Thaumatoneura); presence of at least one accessory secondary antenodal crossvein between $\mathrm{C}$ and ScP distal of Ax2 (unique reversal within Coenagrionidae, also present in Thaumatoneura). However, Anomisma has a very different discoidal cell that is very elongate (instead of short), acute (instead of rectangular), and divided by 2-3 (instead of only one) crossveins. Also, Anomisma has only a single accessory secondary antenodal crossvein instead of three. These differences may suggest a case of convergence rather than synapomorphy, especially since these two characters are highly homoplastic within Zygoptera.

Putative synapomorphies with the extant genus Megaloprepus (Pseudostigmatinae: Megaloprepini) are as follows: discoidal cell not very acute (contrary to other Pseudostigmatinae); longitudinal wing veins being distally distinctly curved to the posterior wing margin (also present in Thaumatoneura); more strongly developed triadic branching pattern of distal part of MP; dark banded colour pattern of wings with sexual dimorphism (as in Thaumatoneura). The absence of intercalary veins between MP and CuA (symplesiomorphy), and the presence of secondary longitudinal veins in area between MP and MA apparently emerging from MP (thus possibly a precursor of the triadic branching of MP in Megaloprepus) are characters that would rather support an attribution of Mesomegaloprepus to Pseudostigmatinae close to Megaloprepus (MP is apically shortly forked in Anomisma and Microstigma, but simple in Coryphagrion, Mecistogaster, and Pseudostigma).

Altogether, the wing venational similarities with Pseudostigmatinae are either very weak characters (pterostigma short and stigmal brace reduced) or clearly convergences (similarities with Megaloprepus), because a subordinate ingroup position of 
Mesomegaloprepus within Pseudostigmatinae is excluded by its plesiomorphic absence of several derived groundplan characters of Pseudostigmatinae and Megaloprepini (see above), while the similarities between Mesomegaloprepus and broad-winged Megaloprepini do not belong to the ground plan of Pseudostigmatinae as documented by the very similar wing venations of the most basal pseudostigmatine genera Coryphagrion, Mecistogaster, and Pseudostigma. The characteristical ligula with single terminal flagellum is a derived similarity of Mesomegaloprepus with Neotropical Pseudostigmatini + Megaloprepini, but it is still absent in Coryphagrionini, and is homoplastic in recent damselflies (e.g., present in the unrelated agriolestid genus Podopteryx Selys, 1871 according to Kalkman and Theischinger, 2013), so that it also represents a weak and conflicting character. Consequently, there is no conclusive evidence to establish a phylogenetic relationship of Mesomegaloprepus with the Pseudostigmatinae. 2014)

\subsubsection{Comparison with Thaumatoneuridae Tillyard and Fraser, 1938 (sensu Dijkstra,}

Recent Thaumatoneuridae are endemic to the Neotropics and only include the two genera Thaumatoneura McLachlan, 1897 (one species T. inopinata) and Paraphlebia Selys, 1862 (four species) (Dijkstra et al., 2014) from Central America, which all are relatively large damselflies typically found in the vicinity of waterfall habitats (“waterfall damsels”). Females have hyaline wings, while males are typically dimorphic with either hyaline wings or distinct dark colour pattern (Calvert, 1914; González-Soriano and Córdoba-Aguilar, 2003; RomoBeltrán, 2009).

A close relationship of the Recent genera Thaumatoneura and Paraphlebia was previously suggested based on adult and larval morphology (Novelo-Gutiérrez, 2008; 
435 Garrison et al., 2010). It has been confirmed with modern phylogenomic studies (Fogarty et al., 2008; Dijkstra, 2014).

Bechly (1996, 2003) considered that the Thaumatoneuridae are related to the Amphipterygoidea within the jewelwing clade Eucaloptera (Calopterygoidea sensu Dijkstra et al., 2013). Dijkstra et al. (2014) suggested a somewhat different phylogeny for Thaumatoneuridae in a clade that comprises several genera previously considered as “Megapodagrionidae”, and this whole clade being sister group of a clade that comprises the Philogeniidae, Amphipterygidae, Lestoideidae, and Epallagidae (= Euphaeidae).

The fact that two South East Asian “megapodagrionid” damselfly genera (viz. Bornargiolestes Kimmins, 1936 and Burmargiolestes Kennedy, 1925) have been proposed by Dijkstra et al. (2014) as closest relatives of Thaumatoneuridae, could suggest that a stemThaumatoneuridae from Burmese amber would not be an unlikely discovery. All fossil taxa that previously have been attributed to Thaumatoneuridae are rather of dubious relationship and are revised below.

Putative synapomorphies of Mesomegaloprepus with extant Thaumatoneuridae (Paraphlebia + Thaumatoneura) (see Bechly, 1996, 2003) are as follows: dark banded colour pattern of wings with sexual dimorphism (as in Megaloprepus); dense wing venation with several hundreds of cells; nodus in very basal position, correlated with large number of postnodal crossveins (as in Pseudostigmatinae); triadic branching of CuA; subdiscoidal cell traversed by a crossvein; discoidal cell elongated (as in Pseudostigmatinae); IR2 apparently arising from RP3/4 (as in Pseudostigmatinae); presence of several secondary (intercalary) longitudinal veins in median and radial area. Nevertheless, the following plesiomorphies of Mesomegaloprepus contradict a placement in the crown group of Thaumatoneuridae: small size; several antesubnodal crossveins; only a single row of cells between RA and RP1 distal of pterostigma; absence of intercalary veins between MP and CuA. Mesomegaloprepus strongly differs from Thaumatoneuridae in the divided discoidal cell, as well as the very short 
and rectangular pterostigma, while the discoidal cell of Paraphlebia and Thaumatoneura is always undivided and their pterostigmata are very long with a extremely oblique basal side (but also unbraced, which seems to be a symplesiomorphy of Thaumatoneuridae, as the pterostigma of closely related genera like Burmargiolestes is also unbraced). Also the fact that the midfork is not basally recessed between arculus and subnodus in extant Thaumatoneuridae contradicts a relationship with Mesomegaloprepus Further important differences are the position of arculus that is more or less aligned with Ax2 in Thaumatoneuridae but distinctly basal of Ax2 in Mesomegaloprepus, as well as the position of the CuP-vestige ("anal crossing”) that is located in the petiolus in Thaumatoneuridae, while it ends on free vein AA distal of petiolus in Mesomegaloprepus, but the polarity of these two characters is uncertain. An antesubnodal space without any crossveins was proposed by Bechly $(2007,2003)$ as an autapomorphy of Thaumatoneuridae, but of course this character is highly homoplastic and also present in all Lestoidea and Coenagrionoidea (incl. Pseudostigmatinae), but it is absent in Mesomegaloprepus.

Putative synapomorphies with only the extant genus Thaumatoneura: broad wings with very dense wing venation (large number of cells) (as in Pseudostigmatinae:

Megaloprepini); petiolus very short (still long in Paraphlebia); nodus even in more basal position, correlated with large number of postnodal crossveins; presence of a few accessory secondary antenodal crossveins between C and ScP distal of Ax2 (3 in Mesomegaloprepus, 12 in Thaumatoneura, none in Paraphlebia); discoidal cell rectangular with distal side MAb with reversed obliquity (still acute in Paraphlebia); subdiscoidal cell traversed by 1-2 crossveins (however the subdiscoidal cell of Thaumatoneura is of very different shape and much longer); postnodal and postsubnodal crossveins secondarily non-aligned (still aligned in Paraphlebia); greatly expanded cubital area; CuA with numerous curved posterior branches and characteristical triadic branching pattern of CuA (similar to Megaloprepus, but CuA much shorter); longitudinal veins distally distinctly curved towards hind margin of wing; base 


\section{7 family}

of RP2 very far distal of subnodus as in Pseudostigmatinae: Megaloprepini). In the anal area of Mesomegaloprepus, there is a series of small transverse cells between AA and AP below the subdiscoidal space, which is a character state also present in Thaumatoneura, but the Pseudostigmatinae also have small crossveins in the anal area between AA and AP below the subdiscoidal space. However, the anal area is distinctly narrower in Pseudostigmatinae than in Mesomegaloprepus and Thaumatoneura, but it is even narrower in Paraphlebia (second modern genus of Thaumatoneuridae). Even though all these character states seem to be derived in Thaumatoneura, as suggested by the more "megapodagrionid”-like sister genus Paraphlebia and the closely related genera Bornargiolestes and Burmargiolestes as sistergroups, the character polarity is unclear in Mesomegaloprepus, mainly because of the homoplastic distribution of these character states in other damselfly taxa (e.g., multiple secondary antenodal crossveins is generally rather a plesiomorphy in odonates). The fact that other characters (see above) contradict an ingroup position of Mesomegaloprepus within Thaumatoneuridae as sister group of Thaumatoneura, rather suggests that the similarities between these two genera are not synapomorphies.

Mesomegaloprepus strongly differs from the other extant thaumatoneurid genus Paraphlebia in the rectangular and divided discoidal cell, very short petiolus, broad cubital area, and nodus even more strongly basally recessed.

\subsubsection{Ambiguous relationship of Mesomegaloprepidae and justification for this new}

Mesomegaloprepus shows a confusing mosaic of characters shared by either the thaumatoneurid genus Thaumatoneura or the pseudostigmatine genus Megaloprepus, or present in both (sub)families. Mesomegaloprepus differs from the modern representatives of the Thaumatoneuridae and Pseudostigmatinae in the much smaller size, the vestige of vein 
$513 \mathrm{CuP}$ ("anal crossing”) between $\mathrm{M}+\mathrm{Cu}$ and $\mathrm{AA}$ instead of being between $\mathrm{M}+\mathrm{Cu}$ and $\mathrm{A}$, the 514 presence of antesubnodal crossveins, and bases of RP3/4 and IR2 (midfork) basally recessed

515 midway between arculus and nodus instead of being aligned with the subnodus. These

516 differences, as well as the conflicting and thus probably convergent similarities with

517 Latibasaliidae, Thaumatoneuridae, and Pseudostigmatinae, allow us to erect a new family

518 Mesomegaloprepidae, with unresolved relationship within Zygoptera. If Mesomegaloprepidae

519 should turn out to belong to one of the discussed extant family group taxa after all, it could be reclassified as distinct subfamily or tribe within them.

Anyway, the high degree of character conflicts in the wing venational similarities with

522

523

524

525

526

527

Thaumatoneura on the one hand and broad-winged Pseudostigmatinae-Megaloprepini on the

other hand, while lacking more superordinate ground-plan characters of the family group taxa

Thaumatoneuridae and Pseudostigmatinae, is a strong indication that wing venational characters generally are of poor value for the reconstruction of phylogenetic relationships within Odonata. This is also indicated by the strong difference between phylogenetic classifications of damselflies based on wing venational characters (Bechly 1996, 2003) with those based on modern phylogenomic studies (Bybee et al., 2008; Carle et al., 2008; Dumont et al., 2010; Dijkstra et al. 2013, 2014). Because of the notorious incongruence between morphological and molecular evidence in phylogenetic reconstructions it was even suggested to refrain from using morphological data at all (e.g., Scotland et al., 2003), which is of course impossible with fossil taxa (Wiens, 2004).

\subsection{Status of alleged fossil Thaumatoneuridae}

Pongrácz (1935) described Eothaumatoneura from the Eocene of Germany and attributed it to Thaumatoneuridae, but Nel and Paicheler (1994) transferred it to Zygoptera incertae sedis. Bechly (1996, 2003) attributed the mostly Paleogene Dysagrioninae Cockerell, 
1908 (Petrolestes, Congqingia, Dysagrion Scudder, 1878, and Phenacolestes Cockerell, 1908) and Early Cretaceous Euarchistigmatinae (Euarchistigma Carle and Wighton 1990) to Thaumatoneuridae within Amphipterygoidea. Petrulevičius and Nel (2004) considered the Paleogene Latibasalia as possibly related to Dysagrioninae within Amphipterygoidea, but we here transferred this taxon to Epallagoidea (see above). Nel et al. (2005) described Primorilestes from the Eocene of Russia. Nel and Arillo (2006) added Electrophenacolestes from Eocene Baltic amber to Dysagrioninae, and Rust et al. (2008) added Eodysagrion in a separate subfamily Eodysagrioninae (and synonymized Thaumatoneuridae with Dysagrionidae). Nel and Fleck (2014) described an unnamed dysagrionine from the EoceneOligocene of the Isle of Wight. Finally, Zheng et al. (2016c, 2016d) described Palaeodysagrion and Burmadysagrion, both from Burmite. These fossil taxa are discussed below and their phylogenetic position is revised.

Eothaumatoneura ptychoptera Pongrácz, 1935 is a fossil damselfly that is only known from wing fragments of a single specimen from the Middle Eocene (Middle Lutetian, MP13, 44.3 Ma) Geiseltal locality in eastern Germany. Nel and Paicheler (1994) considered that this material as too incompletely preserved to be accurately placed, and therefore transferred this taxon from Thaumatoneuridae to Zygoptera incertae sedis. Nevertheless, the preserved parts of the wing venation of Eothaumatoneura are very similar to the corresponding structures in the extant Neotropical damselfly genus Thaumatoneura, especially in the very long postnodal area, base of RP2 far removed from subnodus, absence of lestine oblique vein 'O', main veins strongly curved posteriorly, presence of 2-3 secondary longitudinal veins in distal part of postdiscoidal area between MA and MP, presence of 4-5 secondary longitudinal veins in distal part of area between MP and CuA, cubital area certainly broad, even if poorly preserved (see Pongrácz, 1935: figs. 11-14). This pattern of venation is not shared by any of the known Paleogene damselfly-like Odonata with large wings (e.g., Sieblosiidae, Dysagrionidae, or even the damsel-dragonfly family Pseudostenolestidae from the Eocene of Messel, Garrouste 
and Nel, 2015). Consequently, there are no arguments against an attribution of Eothaumatoneura ptychoptera to Thaumatoneuridae, which is suggested by the above mentioned wing venational similarities. Therefore, we here propose to restore this fossil taxon in Thaumatoneuridae. Eothaumatoneura seems to be more closely related to the extant genus Thaumatoneura than to the other extant thaumatoneurid genus Paraphlebia, because the wing venation is much more similar to the former genus in several derived character states. Bechly (2003, 2007, 2010) attributed Euarchistigma from the Lower Cretaceous Crato Formation of Brazil to the Thaumatoneuridae (Euarchistigmatini) rather than to the Pseudostigmatinae (as originally proposed by Carle and Wighton, 1990), on the basis of the following putative synapomorphies: antesubnodal space without any crossveins; nodus and bases of IR2 and RP3/4 shifted to an extremely basal position, correlated with a large number of postnodal crossveins; IR2 apparently arising on RP3/4; very dense wing venation with a high number of cells; dark colour pattern of wings; longitudinal wing veins distally distinctly curved to the posterior wing margin. All these characters are also present in at least some modern Pseudostigmatinae, but do mostly not belong to the ground plan of this family. Even though the position of Euarchistigma remains somewhat unclear, we here tentatively retain it in Thaumatoneuridae as Euarchistigmatinae stat rest. Mesomegaloprepus differs from Euarchistigma in the presence of three secondary antenodal crossveins, presence of several rows of cells in cubital area, intercalary veins present between main longitudinal veins, triadic branching pattern of CuA and MP (Bechly, 2007, 2010).

The Dysagrioninae are an extinct Cenozoic damselfly group, with the sole exception of Congqingia from the Cretaceous of China. The placement of the Dysagrioninae (Dysagrionini Cockerell, 1908 and Petrolestini Cockerell, 1927) within the Thaumatoneuridae, as proposed by Bechly (1996, 2003) and Rust et al. (2008) is only supported by two very weak alleged synapomorphies: basal costal margin between wing base and nodus is distinctly convex curved; antesubnodal space without any crossveins. The first 
character is probably correlated to the shortening the antenodal space and could have been convergently acquired. The second character is present in several unrelated clades, and thus very homoplastic, as already indicated above. Since the affinities of the Dysagrioninae are uncertain, we prefer to exclude these damselflies from the Thaumatoneuridae and suggest to restate the Dysagrionini and Petrolestini as subfamilies to a separate family Dysagrionidae stat. rest., as already suggested by Garrouste and Nel (2015) and Zheng et al. (2016d). Our rejection of the synonymy of Thaumatoneuridae with Dysagrionidae (contra Rust et al., 2008) implies that Thaumatoneuridae is restored as valid family as well. The Dysagrioninae are characterized by a potential synapomorphy, viz a rather unique shape of the discoidal cell with a distal side distinctly longer than its basal side and anterior and posterior sides not parallel, even if it is also present in the Cenozoic Sieblosiidae. Mesomegaloprepus does not share the above mentioned two potential synapomorphies of Dysagrioninae and Thaumatoneuridae, and also lacks the typical dysagrionine shape of the discoidal cell.

Eodysagrion Rust et al., 2008 from the Paleogene of Denmark was placed in a separate subfamily Eodysagrioninae within Dysagrionidae (Rust et al., 2008). Eodysagrion shares two apomorphies with the Thaumatoneurinae: discoidal cell perfectly rectangular; and IR2 apparently arising on RP3/4. Also, in Eodysagrion, the broadening of the antenodal area, typical of Thaumatoneura, is weakly indicated, and the dark banded colour pattern of the wings may correspond as well. However, Eodysagrion differs markedly from Thaumatoneura in its clearly less numerous secondary longitudinal veins, its nodus not in a very basal position, less numerous postdiscoidal crossveins, and its longitudinal wing veins not distinctly curved distal to the posterior wing margin. Note that the Eodysagrion and Euarchistigma do not have the discoidal cell of 'sieblosiid' type as in Dysagrioninae. Nevertheless, we provisionally maintain Eodysagrion in the Thaumatoneuridae. Mesomegaloprepus differs from Eodysagrion in the presence of three secondary antenodal crossveins, and a different pattern of veins in the cubital area (Rust et al., 2008). 


\subsection{Palaeobiogeography and Palaeoecology}

619

620

621

622

623

624

625

626

627

628

629

630

631

632

633

634

635

636

637

638

639

640

641

Even though the evidence for phylogenetic relationships of Mesomegaloprepidae still

is ambiguous, the three most likely candidates for sister group are all Neotropical taxa.

Together with an unequivocal fossil Thaumatoneuridae from the Eocene of Europe, our new discovery may suggest a great antiquity and wide past distribution for at least some of these Neotropical damselfly groups.

The fact that we have the surprising number of six pieces of Burmite amber with totally 11 conspecific specimens (three pieces contain both sexes) of this new damselfly taxon strongly suggests that it was a rather abundant element of the Myanmar amber forest. Most probably these insects oviposited like modern Pseudostigmatinae in phytotelmata on the amber tree, and also mated there, because this would have greatly increased the likelihood of getting trapped in tree resin, and therefore could explain the relatively large number of inclusions. This could even be a further hint towards a pseudostigmatine relationship of Mesomegaloprepidae, because recent males of Pseudostigmatinae defend large water-filled tree holes as breeding territories, where they mate with multiple females that oviposit in the tree hole, where the cannibalistic larvae develop (Fincke, 1984, 1992a, 1992b, 1996, 2006).

\section{Concluding remarks}

This fossil damselfly represents a new family, genus, and species from midCretaceous amber from Myanmar, with ambiguous phylogenetic relationships to modern Neotropical taxa. It adds to our knowledge of the diverse entomofauna of Burmese amber, and to our knowledge of Mesozoic damselflies and their palaeobiogeographic distribution. 
643

644

645

646

647

648

649

650

651

652

653

654

655

656

657

658

659

660

661

662

663

664

665

666

667

668

\section{Acknowledgments}

GB thanks Sieghard Ellenberger (Kassel, Germany) for providing the paratype Bu-231 to SMNS and for macro-photos of this specimen. HDY is grateful to National Basic Research Program of China (2012CB821903), Outstanding Youth Foundation of Jiangsu Province (BK 2012049), and the National Natural Science Foundation of China (91114201) for supporting funds. DA wants to thank the Chinese Academy of Sciences for the financial support under the CAS President's International Fellowship Initiative (PIFI). This paper is a contribution of the team project “Biodiversity: Origin, Structure, Evolution and Geology” and to the activity of the laboratory “Advanced Micropalaeontology, Biodiversity and Evolution Researches (AMBER)” led by Dany Azar at the Lebanese University.

\section{References}

Bechly, G., 1996. Morphologische Untersuchungen am Flügelgeäder der rezenten Libellen und deren Stammgruppenvertreter (Insecta; Pterygota; Odonata), unter besonderer Berücksichtigung der Phylogenetischen Systematik und des Grundplanes der Odonata. Petalura, Böblingen, Special Volume 2, 402 pp.

Bechly, G., 2003. Phylogenetic Systematics of Odonata. In: Schorr, M., Lindeboom, M. (Eds.), Dragonfly Research 1.2003 (CD-ROM) (also online at: https://dl.dropboxusercontent.com/u/13756162/Website/odonata/phylosys.htm).

Bechly, G., 2007. Odonata: damselflies and dragonflies. In: Martill, D., Bechly, G., Loveridge, R. (Eds.), The Crato fossil beds of Brazil: Window into an ancient world. Cambridge University Press, Cambridge, 624 pp., 184-222.

Bechly, G., 2010. Additions to the fossil dragonfly fauna from the Lower Cretaceous Crato Formation of Brazil (Insecta: Odonata). Palaeodiversity 3 (Supplement), 11-77. 
669 Brodribb, T.J., Feild, T.S., 2008. Evolutionary significance of a flat-leaved Pinus in

670

671

672

673

674

675

676

677

678

679

680

681

682

683

684

685

686

687

688

689

690

691

692 Vietnamese rainforest. New Phytologist 178, 201-209.

Bybee, S.M., Ogden, T.H., Branham, M.A., Whiting, M.F., 2008. Molecules, morphology and fossils: a comprehensive approach to odonate phylogeny and the evolution of the odonate wing. Cladistics 24, 477-514.

Calvert, P.P., 1914. Studies on Costa Rica Odonata. V. The waterfall-dwellers: Thaumatoneura imagos and possible male dimorphism. Entomological News 25, 337348.

Calvert, P.P., 1915a. Studies on Costa Rica Odonata. VI. The waterfall-dwellers: the transformation, external features and attached diatoms of Thaumatoneura larva. Entomological News 26, 295-305.

Calvert, P.P., 1915b. Studies on Costa Rica Odonata. VII. The waterfall-dwellers: The internal organs of Thaumatoneura larva and the respiration and rectal tracheation of zygopterous larvae in general. Entomological News 26(9), 385-393.

Carle, F.L., Wighton, D.C., 1990. Odonata. Bulletin of the American Museum of Natural History 195, 51-68.

Carle, F.L., Kjer, K.M., May, M.L., 2008. Evolution of Odonata, with special reference to Coenagrionoidea (Zygoptera). Arthropod Systematics \& Phylogeny 66, 37-44.

Clausnitzer, V., 2002. IDF-Report 4(1), 11-17.

Clausnitzer, V., Lindeboom, M., 2002. Natural history and description of the dendrolimnetic larvae of Coryphagrion grandis (Odonata). International Journal of Odonatology 5, 29-44.

Cruickshank, R.D., Ko, K., 2003. Geology of an amber locality in the Hukaung Valley, northern Myanmar. Journal of Asian Earth Sciences 21, 441-455. 
693

694

695

696

697

698

699

700

701

702

703

704

705

706

707

708

709

710

711

712

713

714

715

716

Davis, R.B., Nicholson, D.B., Saunders, E.L.R., Mayhew, P.J., 2011. Fossil gaps inferred from phylogenies alter the apparent nature of diversification in dragonflies and their relatives. BMC Evolutionary Biology 11(252), 1-10.

Dijkstra, K.-D.B., Bechly, G. Bybee, S.N., Dow, R.A., Dumont, H.J., Fleck, G., Garrison, R.W., Hämäläinen, M., Kalkman, V.J., Karube, H., May, M.L., Orr, A.G., Paulson, D., Rehn, A.C., Theischinger, G., Trueman, J.W.H., Tol, J.v., von Ellenrieder, N., Ware, J., 2013. The classification of dragonflies and damselflies (Odonata). Zootaxa 3703(1), 036-045.

Dijkstra, K.-D.B., Kalkman, V.J., Dow, R.A., Stokvis, F.R., Van Tol, J., 2014. Redefining the damselfly families: a comprehensive molecular phylogeny of Zygoptera (Odonata). Systematic Entomology 39(1), 68-96.

Dow, R.A., 2014. A review of the genus Bornargiolestes Kimmins, 1936 (Odonata: Zygoptera) with a description of two new species from Sarawak, Malaysia. Journal of Threatened Taxa 6(5), 5700-5711.

Dumont, H.J., Vierstraete, A., Vanfleteren, J.R., 2010. A molecular phylogeny of the Odonata (Insecta). Systematic Entomology 35, 6-18.

Dutta, S., Mallick, M., Kumar, K., Mann, U., Greewood, P.F., 2011. Terpenoid composition and botanical affinity of Cretaceous resins from India and Myanmar. International Journal of Coal Geology 85, 49-55.

Fincke, O.M., 1984. Giant damselflies in a tropical forest: reproductive biology of Megaloprepus coerulatus with notes on Mecistogaster (Zygoptera: Pseudostigmatidae). Advances in Odonatology 2, 13-27.

Fincke, O.M., 1992a. Consequences of larval ecology for territoriality and reproductive success of a Neotropical damselfly. Ecology 73, 49-462. 
Fincke, O.M., 1992b. Interspecific competition for tree holes: consequences for mating systems and coexistence in Neotropical damselflies. The American Naturalist 139(1), 80-101.

Fincke, O.M., 1996. Larval behaviour of a giant damselfly: territoriality or size-dependent dominance? Animal Behaviour 51, 77-87.

Fincke, O.M., 2006. Use of forest and tree species, and dispersal by giant damselflies (Pseudostigmatidae): their prospects in fragmented forests. In Cordero Rivera, A. (Ed.), Forests and dragonflies (4th WDA Symposium of Odonatology, Pontevedra, Spain, July 2005), Sofia-Moscow. Pensoft, 103-125.

Fogarty, F.A., Bybee, S.M., Ingley, S.J., Branham, M.A., 2008. Phylogenetic relationships of Central and South American flatwing damselflies (Odonata: Zygoptera: Megapodagrionidae): An examination of monophyly in a convoluted group. Poster Presentation at the Annual Meeting of the Entomological Society of America, November 16-19, 2008. (https://esa.confex.com/esa/2008/webprogram/Paper37035.html).

Garrison, R.W., von Ellenrieder, N. and Louton, J.A., 2010. Damselfly genera of the New World, an illustrated and annotated key to the Zygoptera. The Johns Hopkins University Press, Baltimore.

Garrouste, R., Nel, A., 2015. New Eocene damselflies and first Cenozoic damsel-dragonfly of the isophlebiopteran lineage (Insecta: Odonata). Zootaxa 4028, 354-366.

González-Soriano, E., Córdoba-Aguilar, A., 2003. Sexual behaviour in Paraphlebia quinta Calvert: male dimorphism and a possible example of odonate female control (Zygoptera: Megapodagrionidae). Odonatologica 32, 345-353.

Grimaldi, D., 2016. Diverse orthorrhaphan flies (Insecta: Diptera: Brachycera) in amber from the Cretaceous of Myanmar: Brachycera in Cretaceous amber, Part VII. Bulletin of the American Museum of Natural History 408, 1-131. 
Grimaldi, D., Engel, M.S., Nascimbene, P., 2002. Fossiliferous Cretaceous amber from Myanmar (Burma): its rediscovery, biotic diversity, and paleontological significance. American Museum Novitates 3361, 1-72.

Grimaldi, D., Ross, A.S., (in press). Extraordinary Lagerstaetten in amber, with particular reference to the Cretaceous of Burma. In: Fraser, N.C., Sues, H.-D. (eds). Terrestrial Conservation Lagerstätten: Windows into the Evolution of Life on Land. Dunedin Press, Edinburgh, UK.

Groeneveld, L.F., Clausnitzer, V., Hadrys, H., 2007. Convergent evolution of gigantism in damselflies of Africa and South America? Evidence from nuclear and mitochondrial sequence data. Molecular Phylogenetics and Evolution 42, 339-346.

Huang, D., Azar, D., Cai, C., Nel, A., 2015. New damselfly genera in the Cretaceous Burmese amber attributable to the Platystictidae and Platycnemididae Disparoneurinae (Odonata: Zygoptera). Cretaceous Research 56, 237-243.

Ingley, S.J., Bybee, S.M., Tennessen, K.J., Whiting, M.F., Branham, M.A., 2012. Life on the fly: phylogenetics and evolution of the helicopter damselflies (Odonata, Pseudostigmatidae). Zoologica Scripta 41(6), 637-650.

Kalkman, V.J., Choong, C.Y., Orr, A.G., Schütte, K., 2010. Remarks on the taxonomy of Megapodagrionidae with emphasis on the larval gills (Odonata). International Journal of Odonatology 13(1), 119-135.

Kalkman, V.J., Theischinger, G., 2013. Generic revision of the Argiolestidae (Odonata), with four new genera. International Journal of Odonatology 16(1), 1-52.

Kimmins, D.E., 1931. Description of the male of Coryphagrion grandis Morton (Odonata). Annals and Magazine of Natural History (10)7, 215-217.

Lounibos, L.P., 1980. Larval Odonata in water-containing treeholes at the Kenya coast. Notulae odonatologicae 1: 99-100. 
Metcalfe, I., 2011. Palaeozoic-Mesozoic history of SE Asia. In: Hall, R., Cottam, M.A., Wilson, M.E.J. (Eds.), The SE Asian gateway: history and tectonics of the AustraliaAsia collision. Geological Society of London, Special Publications 355, 7-35.

Möstel, C., Schorr, M., Bechly, G., in press. A new stem-coenagrionoid genus of damselflies (Odonata: Zygoptera) from mid-Cretaceous Burmese amber. Zootaxa.

Morton, K.J., 1924. A new genus and new species of dragonfly from East Africa belonging to the legion Podagrion (Odonata). The Entomologist 57(737), 217-220.

Nel, A., Arillo, A., 2006. The first Baltic amber dysagrionine damselfly (Odonata: Zygoptera: Thaumatoneuridae: Dysagrioninae). Annales de la Société Entomologique de France (N.S.) 42, 179-182.

Nel, A., Fleck, G., 2014. Dragonflies and damselflies (Insecta: Odonata) from the Late Eocene of the Isle of Wight. Earth and Environmental Science Transactions of the Royal Society of Edinburgh 104, 283-306.

Nel, A., Martinez-Delclos, X., Paicheler, J.-C., Henrotay, M., 1993. Les ‘Anisozygoptera’ fossiles. Phylogénie et classification (Odonata). Martinia, Numéro Hors Série 3, 1311.

Nel, A., Paicheler, J.-C., 1994. Les Lestoidea (Odonata, Zygoptera) fossiles: un inventaire critique. Annales de Paléontologie 80(1), 1-59.

Nel, A., Petrulevicius, J.F., Jarzembowski, E.A., 2005. New fossil Odonata from the European Cenozoic (Insecta: Odonata: Thaumatoneuridae, Aeshnidae, Idionychidae, Libellulidae). Neues Jahrbuch für Geologie und Paläontologie, Abhandlungen 235(3), 343-380.

Novelo-Gutiérrez, R., 2008. Description of the larva of Paraphlebia zoe Selys in Hagen, 1861 (Odonata: Megapodagrionidae). Zootaxa 1876, 29-34.

Petrulevičius, J.F., Nel, A., 2004. A new damselfly family from the Upper Palaeocene of Argentina. Palaeontology 47(1), 109-116. 
Petrulevičius, J.F., Nel, A., 2007. Enigmatic and little known Odonata (Insecta) from the Paleogene of Patagonia and Northwest Argentina. Annales de la Société Entomologique de France (N.S.) 43(3), 341-347.

Poinar, G., Jr., Bechly, G., Buckley, R., 2010. First record of Odonata and a new subfamily of damselflies from early Cretaceous Burmese amber. Paleodiversity 3, 15-22.

Poinar, G.O., Jr., Lambert, J.B., Wu, Y., 2007. Araucarian source of fossiliferous Burmese amber: spectroscopic and anatomical evidence. Journal of the Botanical Research Institute of Texas 1, 449-455.

Pongrácz, A., 1935. Die eozäne Insektenfauna des Geiseltales. Nova Acta Leopoldina (N.F.) 2, 485-572.

Ramírez, A., 1997. Description and natural history of the Costa Rican Odonata larvae. 5. Megaloprepus caerulatus (Drury, 1782) (Zygoptera, Pseudostigmatidae). Odonatologica 26(1), 75-81.

Rehn, A.C., 2003. Phylogenetic analysis of higher-level relationships of Odonata. Systematic Entomology 28, 181-239.

Riek, E.F., Kukalová-Peck, J., 1984. A new interpretation of dragonfly wing venation based upon Early Carboniferous fossils from Argentina (Insecta: Odonatoidea) and basic characters states in pterygote wings. Canadian Journal of Zoology 62, 1150-1166.

Romo-Beltrán, A., Macías-Ordóñez, R., Córdoba-Aguilar, A., 2009. Male dimorphism, territoriality and mating success in the tropical damselfly, Paraphlebia zoe Selys (Odonata: Megapodagrionidae). Evolutionary Ecology 23: 699-709.

Ross, A., Mellish, C., York, P., Crighton, B., 2010. Burmese amber. In: Penney, D. (Ed.), Biodiversity of fossils in amber from the major world deposits. Siri Scientific Press, Manchester, 208-235. 
Rust, J., Petrulevičius, J., Nel, A. 2008. The first damselflies from the Lowermost Eocene of Denmark, with a description of a new subfamily (Odonata, Zygoptera: Dysagrionidae). Palaeontology 51(3), 709-713.

Schmidt, E., 1915. Vergleichende Morphologie des 2. und 3. Abdominalsegments bei männlichen Libellen. Zoologische Jahrbücher, Anat. 39(1), 87-200, pls 9-11.

Scotland, R.W., Olmstead, R.G., Bennett, J.R., 2003. Phylogeny reconstruction: the role of morphology. Systematic Biology 52(4), 539-548.

Shi, G.-H., Grimaldi, D.A., Harlow, G.E., Wang, J., Yang, M.-C., Lei, W.-Y., Li, Q., Li, X.H., 2012. Age constraints on Burmese amber based on U-Pb dating of zircons. Cretaceous Research 37, 155-163.

Wiens, J.J., 2004. The role of morphological data in phylogeny reconstruction. Systematic Biology 53(4), 653-661.

Yu, X., Bu, W., 2011. A preliminary phylogenetic study of Megapodagrionidae with focus on the Chinese genera Sinocnemis Wilson \& Zhou and Priscagrion Zhou \& Wilson (Odonata: Zygoptera). Hydrobiologia 665, 195-203.

Zahirovic, S., Seton, M., Müller, R.D., 2014. The Cretaceous and Cenozoic tectonic evolution of Southeast Asia. Solid Earth 5, 227-273.

Zheng, D., Zhang, Q., Chang, S.-C., Wang, B., 2016a. A new damselfly (Odonata: Zygoptera: Platystictidae) from mid-Cretaceous Burmese amber. Cretaceous Research 63, 142-147.

Zheng, D. Wang, B., Jarzembowski, E.A., Chang, S.-C, Nel, A., 2016b. The first fossil Perilestidae (Odonata: Zygoptera) from mid-Cretaceous Burmese amber. Cretaceous Research 65, 199-205.

Zheng, D., Wang, B., Chang, S.-C., Nel, A., 2016c. Burmadysagrioninae, a new subfamily (Odonata: Zygoptera: Dysagrionidae) from mid-Cretaceous Burmese amber. Cretaceous Research 67(1), 126-132. 
843 Zheng, D., Zhang, Q., Nel, A., Jarzembowski, E.A., Zhou, Z., Chang, S.-C., Wang, B., (in

844

845

846

847

848

849 press). New damselflies (Odonata: Zygoptera: Hemiphlebiidae, Dysagrionidae) from mid-Cretaceous Burmese amber. Alcheringa, doi:10.1080/03115518.2016.1164402.

Zherikhin, V.V., Ross, A.J., 2000. A review of the history, geology and age of Burmese amber (Burmite). Bulletin of the Natural History Museum, Geological Series 56, 3-10. 
850

851

852

853

854

855

856

857

858

859

860

861

862

863

864

865

866

867

868

869

870

871

872

873

\section{Figures legends}

Figure 1: Mesomegaloprepus magnificus gen. et sp. nov., habitus. a- Holotype, female, NIGP 164902. b- Paratype male NIGP 164903. c- Paratype male NIGP 164904. D- Paratypes, several males and females, NIGP 164950. Scale bars $=1 \mathrm{~cm}$.

Figure 2: Mesomegaloprepus magnificus gen. et sp. nov., habitus. a- Paratypes, several males and females, NIGP 164951. b- Paratype, female, NIGP 161754. c- Allotype, male, NIGP 161753. d- Two photographs of paratype SMNS Bu-231. Scale bars $=1 \mathrm{~cm}$.

Figure 3: Mesomegaloprepus magnificus gen. et sp. nov., head. a- Photograph of head of paratype, male, specimen number NIGP 164904. b- Drawing of head of holotype, female, specimen number NIGP 164902. Scale bar $=1 \mathrm{~cm}$.

Figure 4: Mesomegaloprepus magnificus gen. et sp. nov., photograph of wings of holotype, female, NIGP 164902. a- Forewing. b- Hindwing.

Figure 5: Mesomegaloprepus magnificus gen. et sp. nov., drawing of wings of holotype, female, NIGP 164902. a- Forewing. b- Hindwing. Scale bar $=1 \mathrm{~cm}$.

Figure 6: Mesomegaloprepus magnificus gen. et sp. nov., drawing of wings. a- Forewing of male paratype NIGP 164951. b- Forewing of paratype NIGP 161753, male. c- Forewing of male paratype NIGP 164903. d- Hindwing of male paratype NIGP 164903 . Scale bar $=1 \mathrm{~cm}$. Figure 7: Mesomegaloprepus magnificus gen. et sp. nov., male terminalia; paratype NIGP 164903, ventral side. a- Photograph. b- Drawing. Scale bar $=1 \mathrm{~cm}$.

Figure 8: Mesomegaloprepus magnificus gen. et sp. nov., male genitalia on second abdominal segment; paratype NIGP 164903. a- Photograph of lateral view. b- Photograph of ventrolateral view. c- Drawing of ventro-lateral view. Scale bar $=1 \mathrm{~cm}$. 

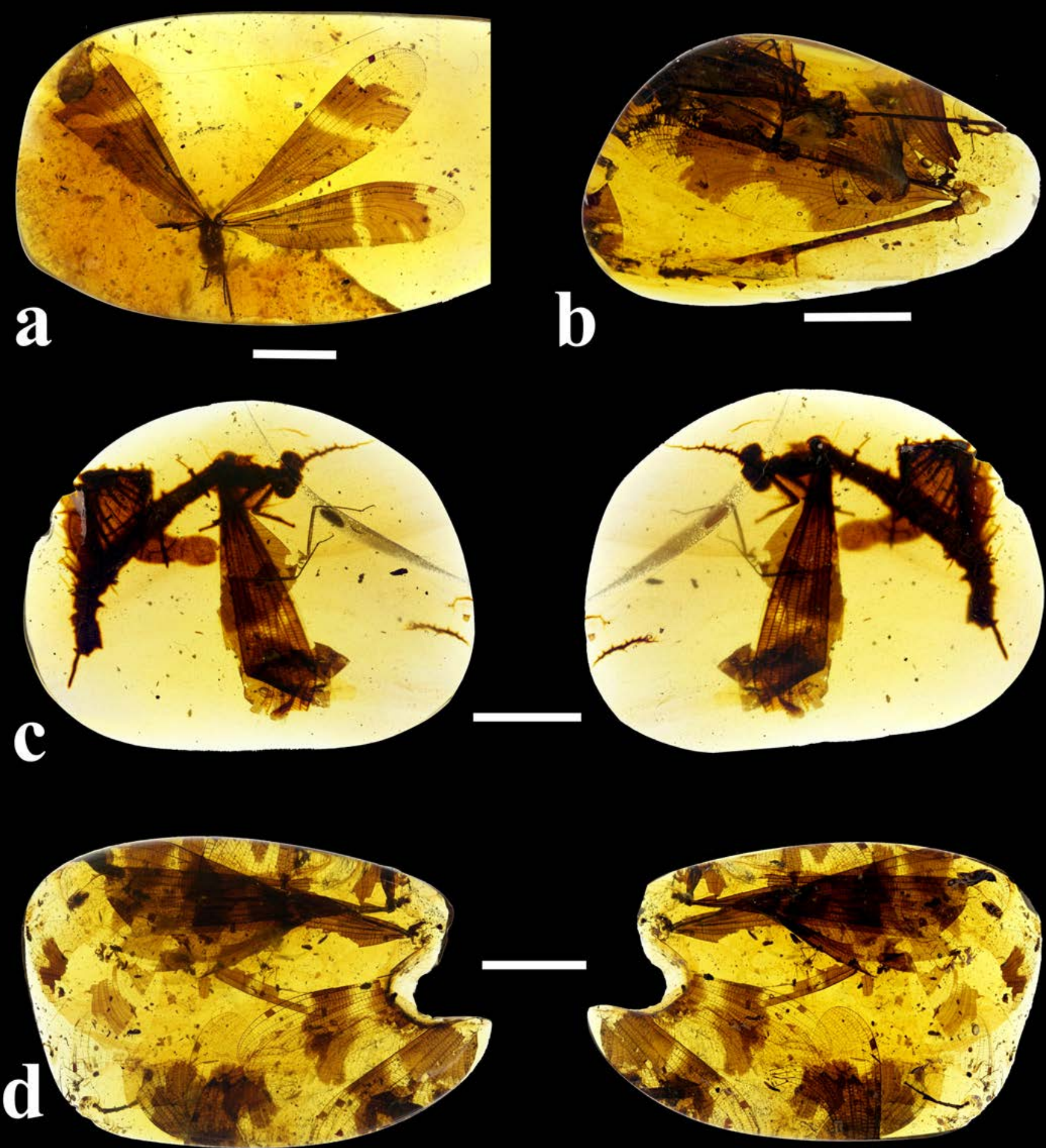

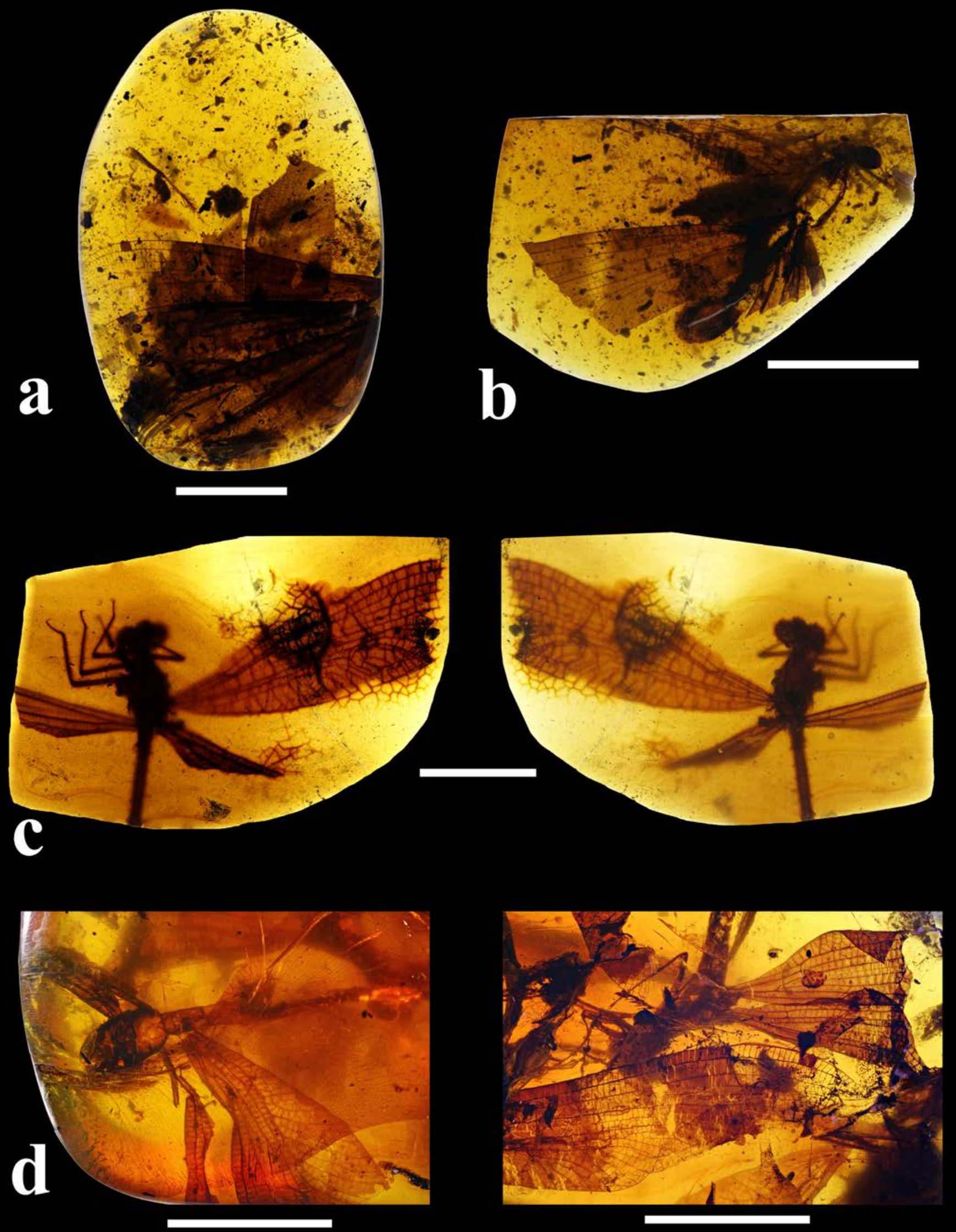

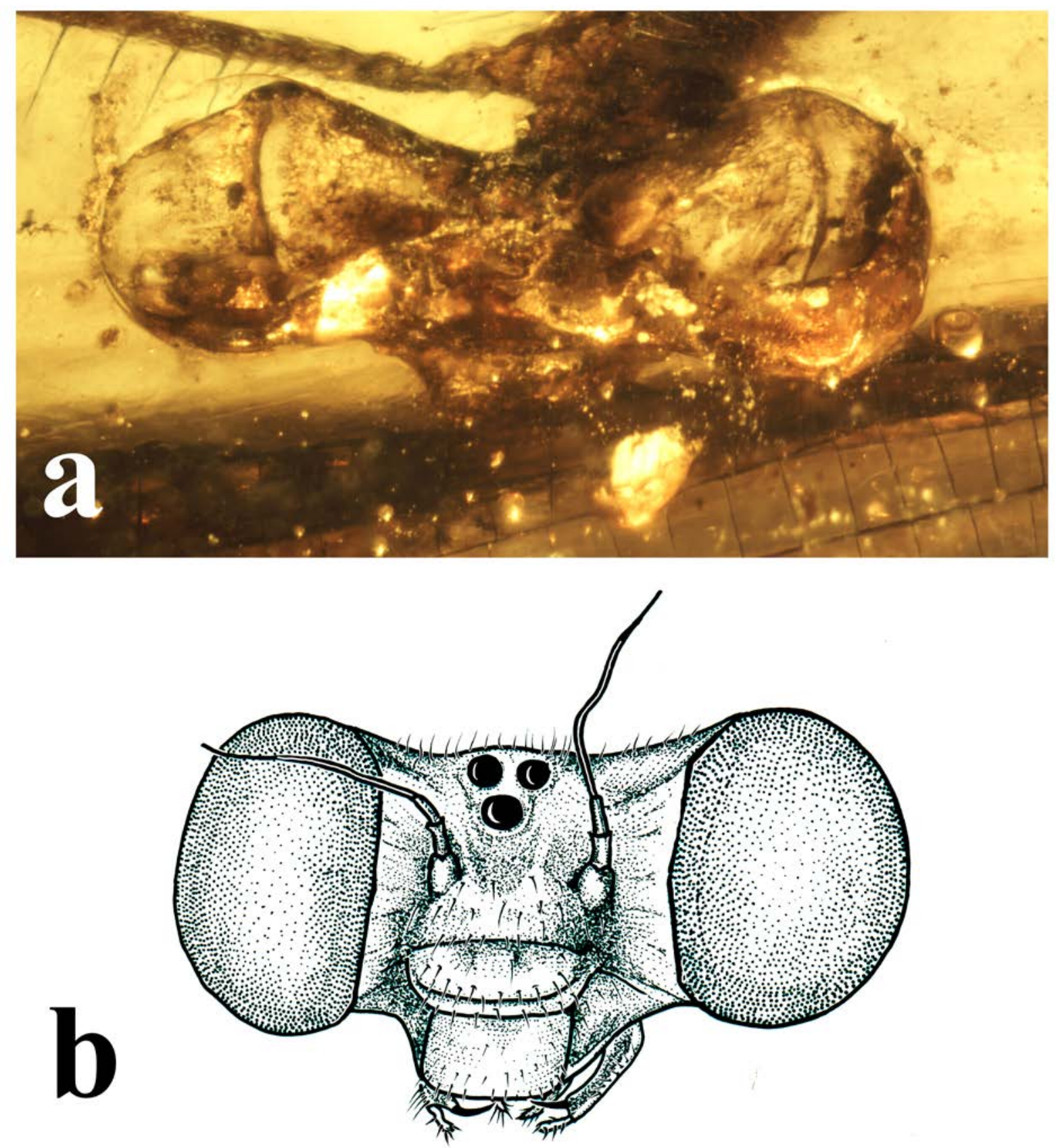

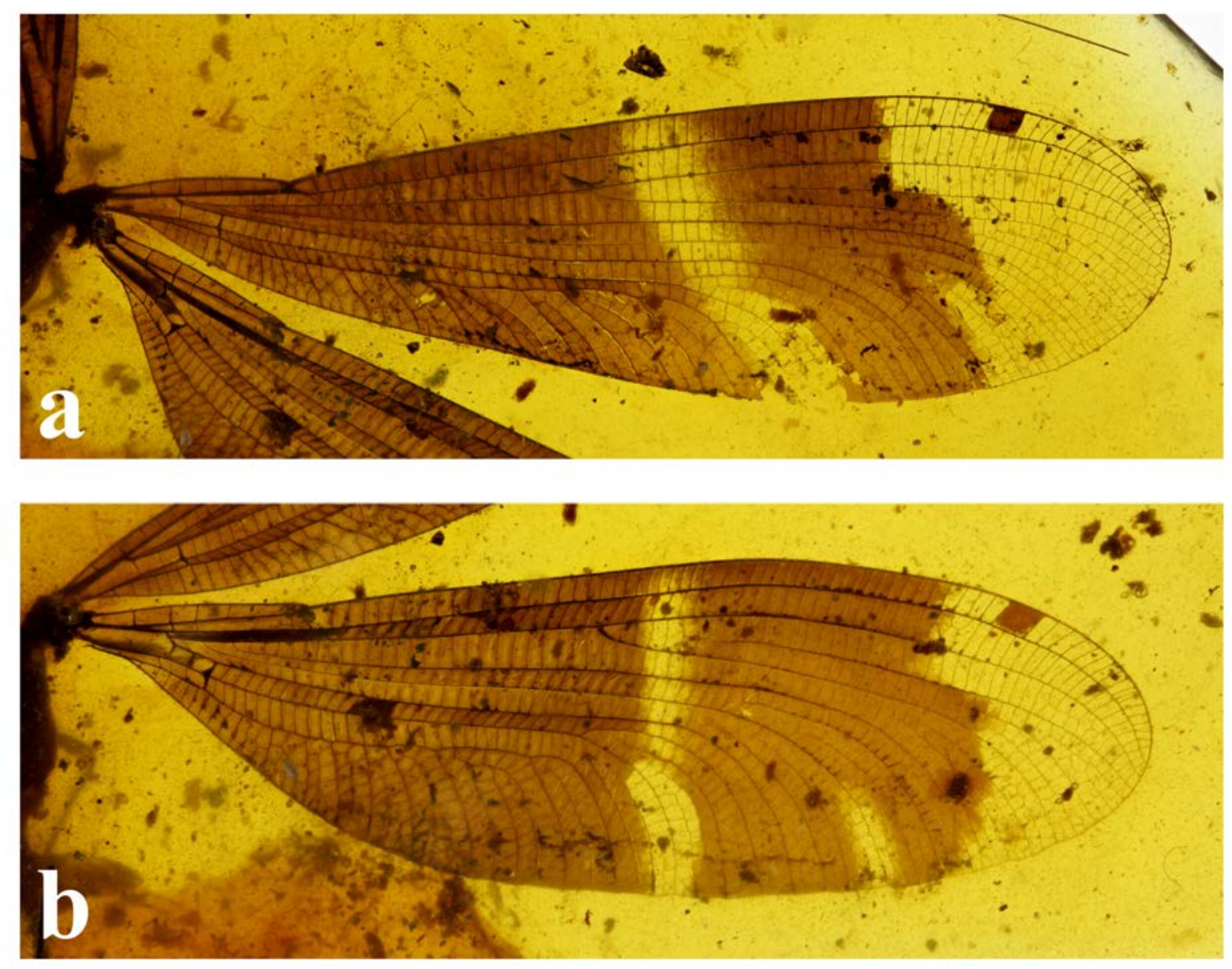


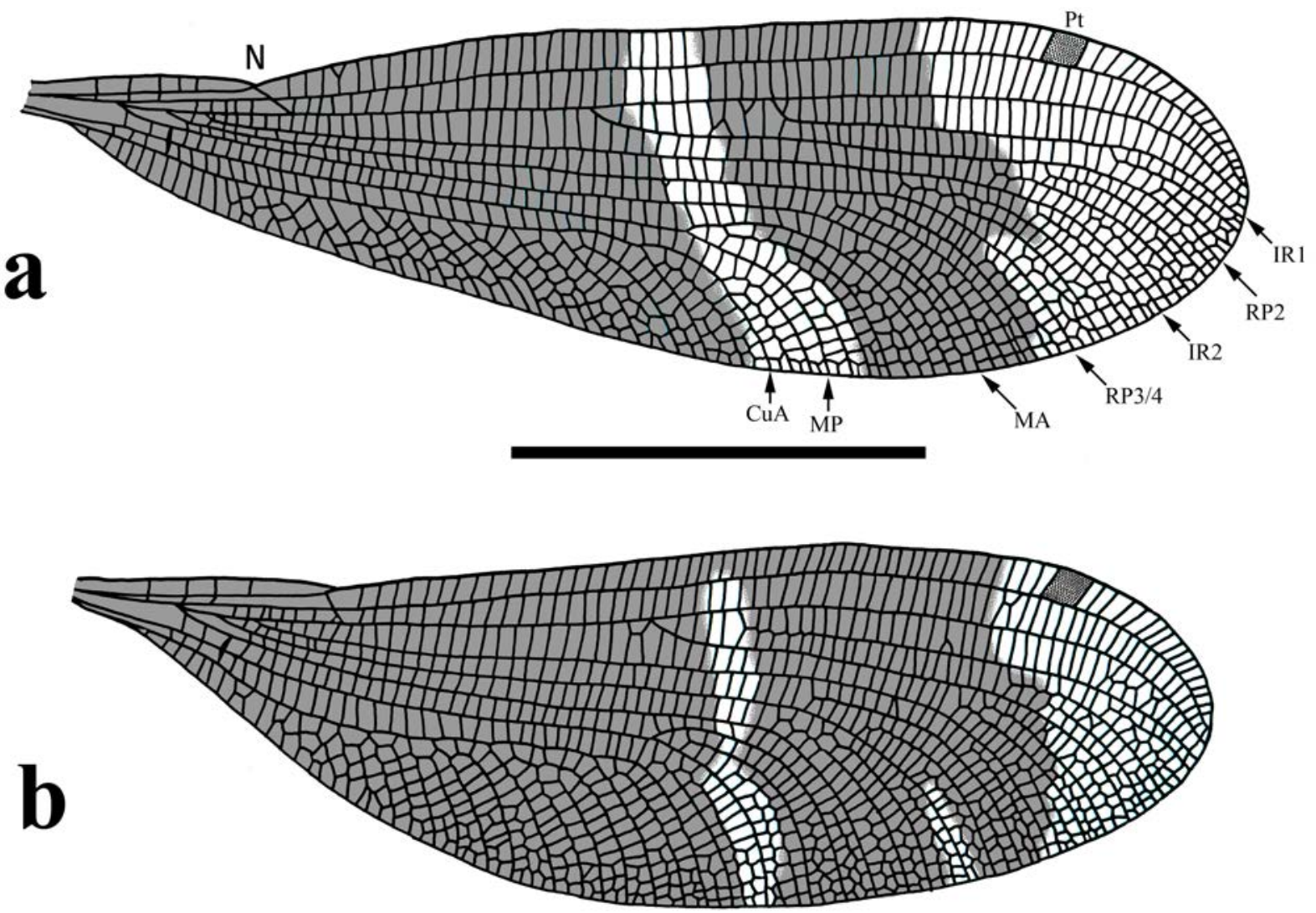



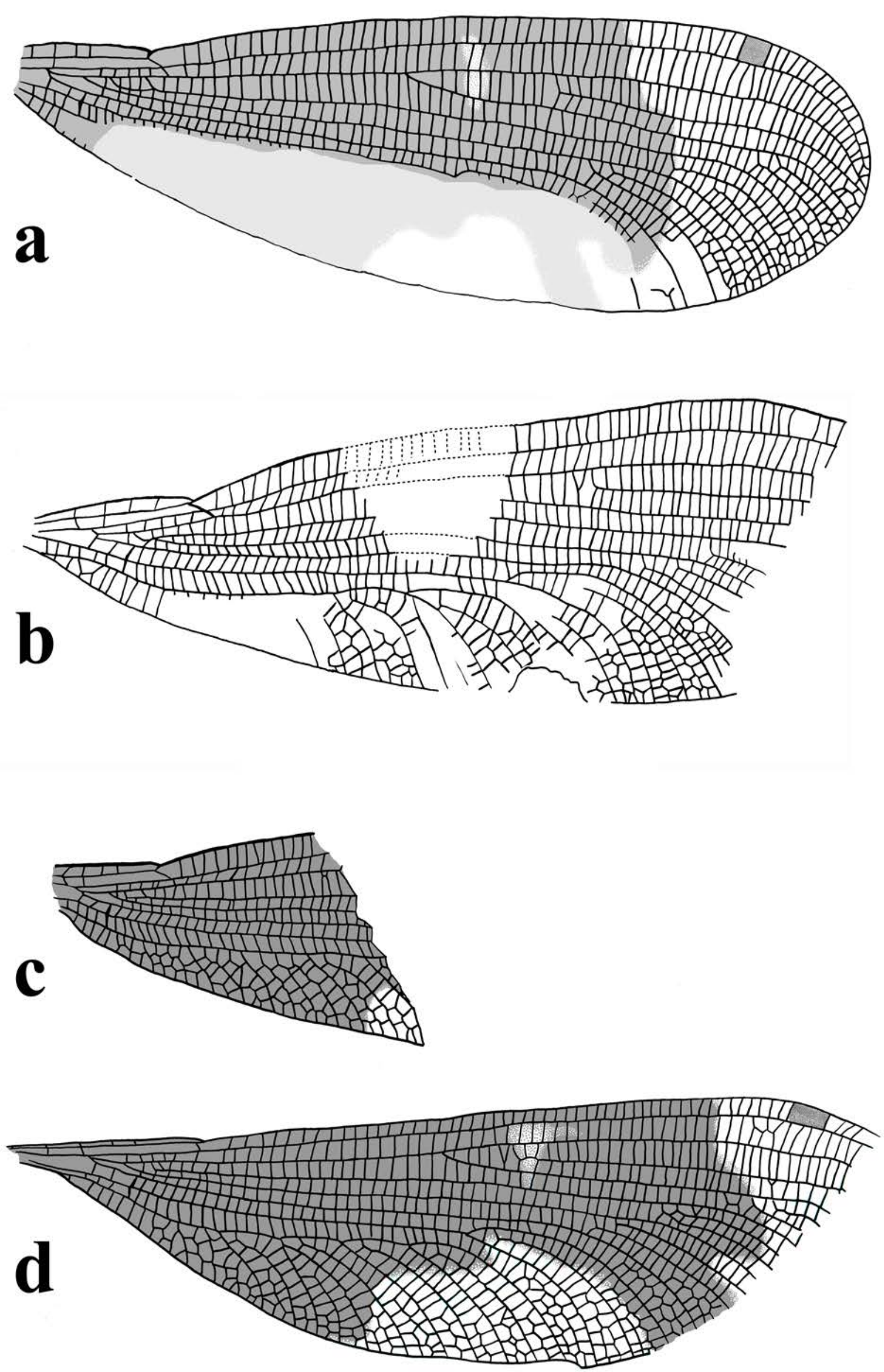


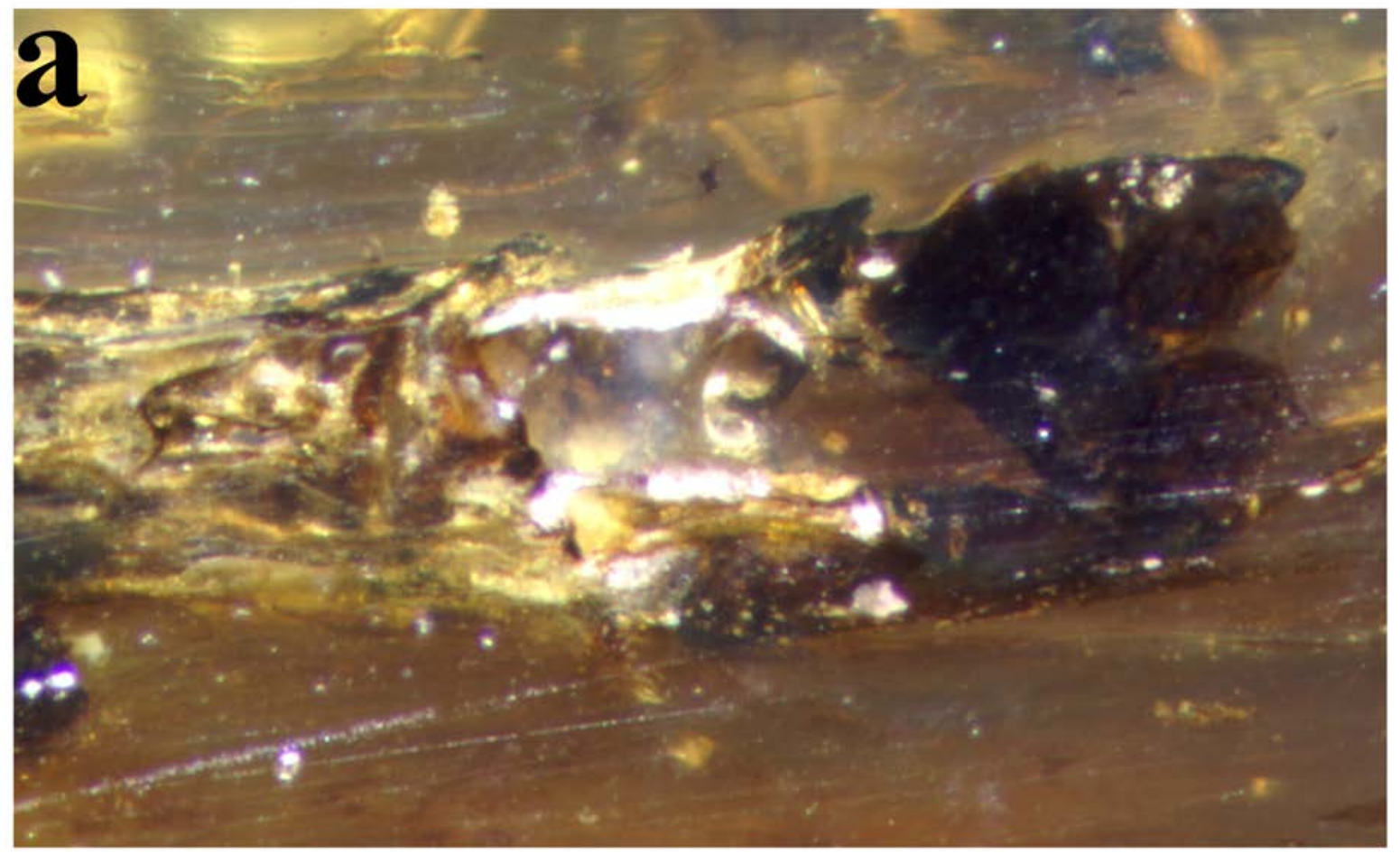

b

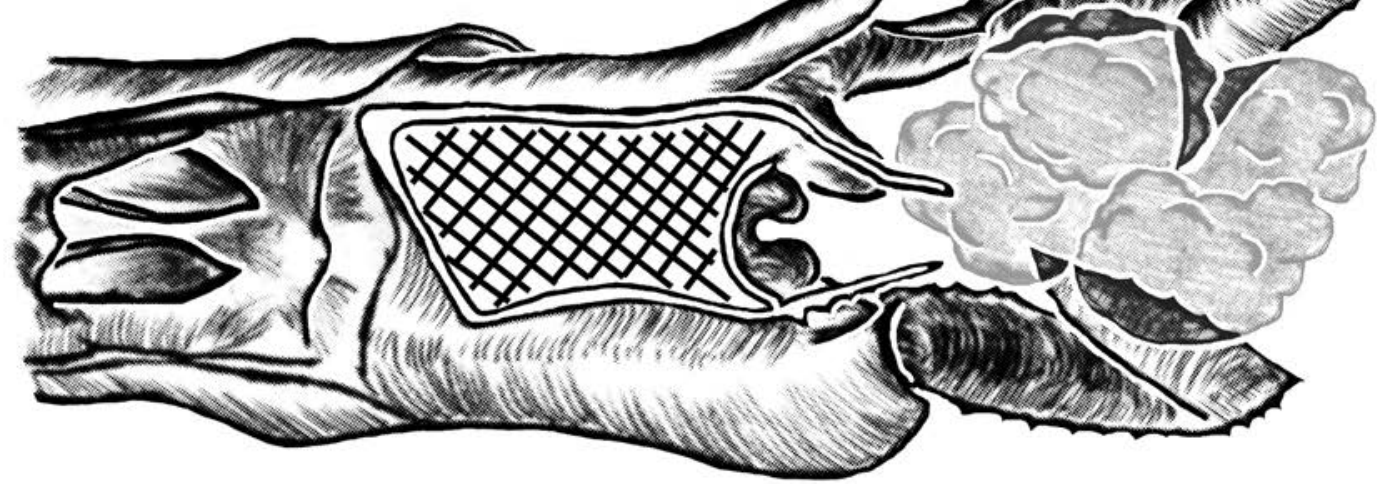




\section{Supplementary material}

Revised classification of discussed fossil damselfly taxa:

Dysagrionidae Cockerell, 1908 (stat. nov. as family by Rust et al., 2008) (in Zygoptera incertae sedis)

Dysagrioninae Cockerell, 1908 stat. rest. (Dysagrionini sensu Bechly, 1996)

Dysagrion Scudder, 1878

D. fredericcii Scudder, 1878 (Eocene, Green River, USA)

D. packardii Scudder, 1885 (Eocene, Green River, USA)

D. lakesii Scudder, 1890 (Eocene, Green River, USA)

Phenacolestes Cockerell, 1908

P. mirandus Cockerell, 1908 (Eocence, Florissant, USA)

P. (?) parallelus Cockerell, 1908 (Eocene, Florrisant, USA)

P. coloratus (Hagen, 1848) (belongs to Phenacolestes according to Nel and Paicheler, 1994) (Miocene, Radoboj, Croatia)

Electrophenacolestes Nel and Arillo, 2006

E. serafini Nel and Arillo, 2006 (Eocene, Baltic amber)

unnamed genus and species Nel and Fleck, 2014 (Eocene-Oligocene, Isle of Wight)

Burmadysagrioninae Zheng et al., 2016

Burmadysagrion Zheng et al., 2016

B. zhangi Zheng et al., 2016 (mid-Cretaceous, Burmite amber, Myanmar)

Petrolestinae Cockerell, 1927 stat. rest. (Petrolestini sensu Bechly, 1996, Congqingiidae Zhang, 1992) 
Primorilestes Nel et al., 2005 pos. nov. (closer to Petrolestinae than to Dysagrioninae, as already suggested by Rust et al., 2008)

P. violetae Nel et al., 2005 (Eocene, Biamo, Russia)

P. madseni Rust et al., 2008 (Paleocene-Eocene, Fur, Denmark)

Petrolestes Cockerell, 1927

P. hendersoni Cockerell, 1927 (Eocene, Green River, USA)

P. messelensis Garrouste and Nel, 2015 (Eocene, Messel, Germany)

Congqingia Zhang, 1992

C. rhora Zhang, 1992 (Early Cretaceous, Laiyang, China)

Subfamily incertae sedis

Palaeodysagrion Zheng et al., 2016

P. cretacicus Zheng et al., 2016 (mid-Cretaceous, Burmite amber, Myanmar)

Latibasaliidae Petrulevičius and Nel, 2004 (transferred from Amphipterygoidea to Epallagoidea as sister group of Zacallitidae)

Latibasalia Petrulevičius and Nel, 2004

L. elongata Petrulevičius and Nel, 2004 (Paleocene, El Fuerte, Argentina)

L. quispeae Petrulevičius and Nel, 2004 (Paleocene, El Fuerte, Argentina)

Mesomegaloprepidae (in Zygoptera incertae sedis)

Mesomegaloprepus gen. nov.

M. magnificus spec. nov. (mid-Cretaceous, Burmite, Myanmar)

Thaumatoneuridae Tillyard and Fraser, 1938 stat. rest. 
Thaumatoneurinae Tillyard and Fraser, 1938

Paraphlebia Selys 1862 (Paraphlebia as used by Hagen, 1861 is a nomen nudum according to Garrison, 1991 unpubl.)

P. duodecima Calvert, 1901 (Recent, Neotropical)

P. hyalina Brauer, 1871 (Recent, Neotropical)

P. quinta Calvert, 1901 (Recent, Neotropical)

P. zoe Selys, 1862 (Hagen, 1861 is a nomen nudum according to Garrison, 1991 unpubl.) (Recent, Neotropical)

Thaumatoneura McLachlan, 1897

T. inopinata McLachlan 1897 (Recent, Neotropical)

Garrison, 1991 unpubl) (Recent)

Euarchistigmatinae Carle and Wighton, 1990 stat. rest.

Euarchistigma Carle and Wighton, 1990

E. atrophium Carle and Wighton, 1990 (Early Cretaceous, Crato, Brazil)

E. marialuiseae Bechly, 2007 (Early Cretaceous, Crato, Brazil)

E. peterknobli Bechly, 2010 (Early Cretaceous, Crato, Brazil)

Eodysagrioninae Rust et al., 2008

Eodysagrion Rust et al., 2008

E. mikkelseni Rust et al., 2008 (Paleocene-Eocene, Fur, Denmark) 